\title{
Lentzea kentuckyensis sp. nov., of equine origin
}

\author{
Correspondence \\ D. P. Labeda \\ David.Labeda@ars.usda.gov
}

\author{
D. P. Labeda, ${ }^{1}$ J. M. Donahue, ${ }^{2}$ S. F. Sells ${ }^{2}$ and R. M. Kroppenstedt ${ }^{3}$ \\ ${ }^{1}$ Microbial Genomics and Bioprocessing Research Unit, National Center for Agricultural Utilization \\ Research, USDA - Agricultural Research Service, Peoria, IL 61604, USA \\ ${ }^{2}$ Livestock Disease Diagnostic Center, Department of Veterinary Science, University of Kentucky, \\ Lexington, KY 40511, USA \\ ${ }^{3}$ DSMZ - German Collection of Microorganisms and Cell Cultures, Braunschweig, Germany
}

\begin{abstract}
A novel actinomycete, designated strain LDDC $2876-05^{\top}$, was isolated from an equine placenta during the course of routine diagnostic tests for nocardioform placentitis. In a preliminary study, the strain was observed to be phylogenetically distinct from the genera Crossiella and

Amycolatopsis and probably a member of the genus Lentzea. A polyphasic study of strain LDDC 2876- $05^{\top}$ confirmed its identification as a member of Lentzea on the basis of its chemotaxonomic and morphological similarity to all of the known species of the genus. Moreover, the strain could be distinguished from other species with validly published names on the basis of its phylogenetic and physiological characteristics and its fatty acid profile. Therefore strain LDDC $2876-05^{\top}$ represents a novel species of the genus Lentzea, for which the name Lentzea kentuckyensis sp. nov. is proposed. The type strain is LDDC $2876-05^{\top}\left(=\right.$ NRRL B- $24416^{\top}=$ DSM $\left.44909^{\top}\right)$.
\end{abstract}

Nocardioform placentitis is a distinctive type of placentitis in horses, in which lesions observed on the chorionic surface of the placenta are associated with Gram-positive, branching micro-organisms that can be recovered upon culture (Donahue \& Williams, 2000; Giles et al., 1993; Hong et al., 1993). The actinomycetes isolated from these lesions are predominantly identified as either Crossiella equi (Donahue et al., 2002) or various Amycolatopsis species (Labeda et al., 2003), but representatives of other actinomycete genera have also been isolated. During the course of evaluating isolates from diagnostic studies of equine placentas during the 2005 breeding season, an actinomycete placental isolate, designated strain LDDC 2876- $05^{\mathrm{T}}$, was obtained that did not belong to the genera Crossiella or Amycolatopsis according to preliminary molecular systematic identification. No gross or histopathological lesions were seen in the placenta, and it was believed that the isolate was a contaminant picked up from the mare's environment during the birthing process. The mare produced a live, healthy foal. A polyphasic study of this strain was undertaken to clarify its taxonomic identity.

The strain was cultivated on NZamine medium (DSMZ medium no. 554; DSMZ, 2001) at $28{ }^{\circ} \mathrm{C}$. Morphological observations were made on the media of Shirling \& Gottlieb (1966) and DSMZ medium no. 554.

Genomic DNA for sequencing was isolated from cells grown on plates containing DSMZ medium no. 554, using

The GenBank/EMBL/DDBJ accession number for the 16S rRNA gene sequence of strain NRRL B- $24416^{\top}\left(=\right.$ LDDC $\left.2876-05^{\top}\right)$ is DQ291145.
UltraClean microbial DNA isolation kits (Mo Bio Laboratories), amplified, sequenced according to previously described procedures (Labeda \& Kroppenstedt, 2000) and then deposited in GenBank. This sequence was aligned, within ARB (Ludwig et al., 2004), against those for taxa in the suborder Pseudonocardineae. The program PHYLO_WIN (Galtier et al., 1996) was used to calculate evolutionary distances according to the method of Kimura (1980) and linkages according to the neighbour-joining method of Saitou \& Nei (1987) and to perform maximum-parsimony and maximum-likelihood analyses. The topographies of the trees resulting from the neighbour-joining and maximumparsimony analyses were evaluated by bootstrap analysis of the data on the basis of 500 resamplings (Felsenstein, 1989).

Genomic DNA for DNA relatedness determinations was isolated from biomass of Lentzea albidocapillata NRRL B-24057 ${ }^{\mathrm{T}}$, Lentzea waywayandensis NRRL B- $16159^{\mathrm{T}}$ and strain LDDC $2876-05^{\mathrm{T}}$ grown for 5 days with shaking at $28{ }^{\circ} \mathrm{C}$ on DSMZ medium no. 554 broth, using PowerMicrobial Maxi DNA isolation kits (Mo Bio Laboratories). The purified DNA was then sheared to $300-500$ bp by passage twice through a French pressure cell (Thermo Fisher Scientific) and levels of DNA relatedness were determined in $5 \times$ SSC $(1 \times$ SSC is $0.15 \mathrm{M}$ sodium chloride and $0.015 \mathrm{M}$ sodium citrate) supplemented with $20 \%$ DMSO as described by De Ley et al. (1970).

For analyses of the fatty acids, approximately $40 \mathrm{mg}$ cells was scraped from agar plates, whereas for the other chemical analyses the cells were grown in liquid medium 
and harvested by centrifugation. Chemotaxonomic analysis of the strains for polar lipids, menaquinones and fatty acids were performed using previously described methods (Grund \& Kroppenstedt, 1989; Minnikin et al., 1984; Sasser, 1990).

Physiological tests, including assessment of the production of acid from carbohydrates, the utilization of organic acids and the hydrolysis and decomposition of adenine, guanine, hypoxanthine, tyrosine, xanthine, casein, aesculin, urea and hippurate, were evaluated by using the media of Gordon et al. (1974). Phosphatase activity was evaluated by using the method of Kurup \& Schmitt (1973). The temperature range for growth was determined on slants of DSMZ medium no. 554.

Phylogenetic analyses clearly demonstrated that strain LDDC $2876-05^{\mathrm{T}}$ represents a species of the genus Lentzea, closely related to Lentzea albida and L. waywayandensis (Fig. 1). Tree topographies for the other algorithms evaluated were very similar. The levels of $16 \mathrm{~S}$ rRNA gene sequence similarity with respect to the type strains of $L$. albida, L. albidocapillata, Lentzea californiensis, Lentzea flaviverrucosa, Lentzea violacea and $L$. waywayandensis, as determined using the GAP algorithm in GCG 11 (Accelrys), were $98.9,97.0,96.8,96.9,97.4$ and $98.4 \%$, respectively. The levels of DNA relatedness between the phylogenetically nearest and most distant Lentzea type strains, L. albidocapillata NRRL B-24057 ${ }^{\mathrm{T}}$ and L. waywayandensis NRRL B- $16159^{\mathrm{T}}$, were determined as 61 and $49 \%$, respectively. Further relatedness determinations were not considered necessary, because both of these values were below $70 \%$ and therefore support the proposal that strain LDDC $2876-05^{\mathrm{T}}$ represents a novel species of the genus Lentzea.

The morphological characteristics of strain LDDC 2876$05^{\mathrm{T}}$, namely the production of aerial mycelium that fragments into rod-shaped elements, are also typical of those of the genus Lentzea. The strain grew well on all of the media evaluated and was observed to produce substrate mycelium that was yellow to deep yellow in colour; no soluble pigments were produced on any of the test media, except peptone-iron agar. White to yellowish-white aerial mycelium was produced on all of the growth media tested.

The cell wall of strain LDDC $2876-05^{\mathrm{T}}$ was observed to contain meso-diaminopimelic acid, and the whole-cell sugars consisted of galactose and ribose. The polar lipids present were phosphatidylethanolamine, hydroxyphosphatidylethanolamine, diphosphatidylglycerol, phosphatidylinositol, traces of phosphatidylinositol mannosides and phosphatidylglycerol. Additionally, two unknown glycolipids were observed. The only menaquinone present was MK-9 $\left(\mathrm{H}_{4}\right)$. As expected, mycolic acids could not be detected. This chemotaxonomic profile is consistent with assignment of strain LDDC $2876-05^{\mathrm{T}}$ to the genus Lentzea. The fatty acid pattern mainly comprises iso/anteisobranched fatty acids and small, but diagnostic, amounts of 2-hydroxy fatty acids. The detailed fatty acid profile for LDDC $2876-05^{\mathrm{T}}$, shown in Table 1, can be used to distinguish the strain from described species of this genus.

The physiological characteristics of strain LDDC $2876-05^{\mathrm{T}}$ are summarized in the formal species description below and the physiological characteristics that serve to distinguish between the species of the genus Lentzea are shown in Table 2.

The chemotaxonomic, morphological and phylogenetic data clearly support the assignment of LDDC $2876-05^{\mathrm{T}}$ to the genus Lentzea, and the physiological and phylogenetic data demonstrate that the strain can be differentiated from described species of the genus Lentzea. Therefore, strain LDDC $2876-05^{\mathrm{T}}$ represents a novel species of the genus Lentzea, for which the name Lentzea kentuckyensis sp. nov. is proposed.

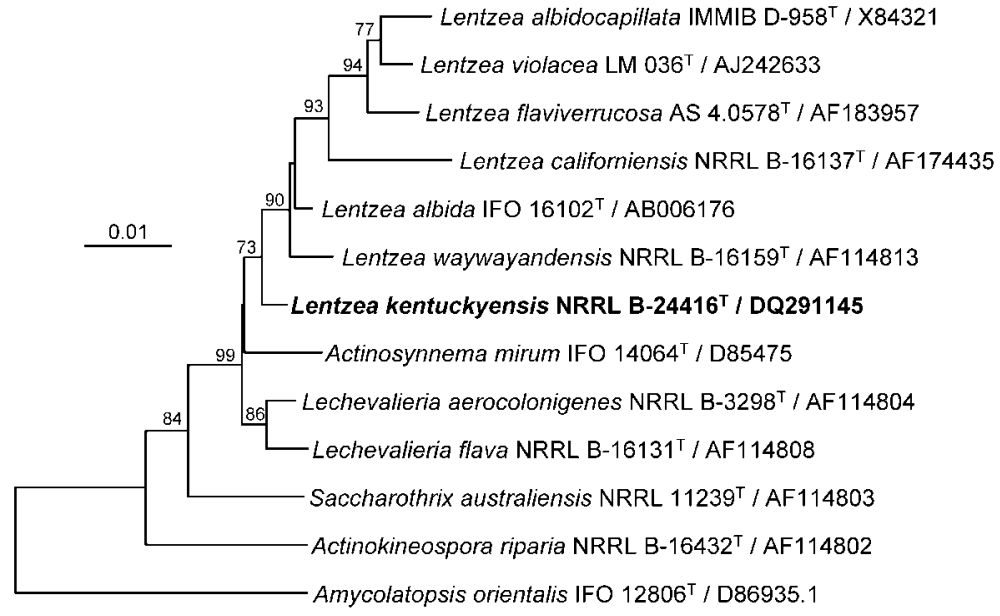

http://ijs.sgmjournals.org
Fig. 1. Phylogenetic tree for strain NRRL B$24416^{\top}$ (=LDDC $2876-05^{\top}$ ), members of the genus Lentzea and representative neighbouring taxa, calculated from 16S rRNA gene sequences using Kimura's evolutionary distance method (Kimura, 1980) and the neighbour-joining method of Saitou \& Nei (1987). Bar, 0.01 nucleotide substitutions per site. 
Table 1. Fatty acid compositions (\%) for strain LDDC 2876$05^{\top}$ and type strains of Lentzea species

Strains: 1, LDDC $2876-05^{\mathrm{T}}$; 2, L. albidocapillata NRRL B-24057 3, L. albida NRRL B- $24073^{\mathrm{T}}$; 4, L. californiensis NRRL B- $16137^{\mathrm{T}} ; 5, L$. flaviverrucosa JCM $113873^{\mathrm{T}} ; 6$, L. violacea IMSNU $50388^{\mathrm{T}} ; 7, L$. waywayandensis NRRL B- $16159^{\mathrm{T}}$. Data were obtained in this study except for L. flaviverrucosa (data from Xie et al., 2002) and L. violacea (data from Lee et al., 2000).

\begin{tabular}{|c|c|c|c|c|c|c|c|}
\hline Fatty acid & 1 & 2 & 3 & 4 & 5 & 6 & 7 \\
\hline $13: 0$ iso & 0.19 & - & 0.46 & - & - & - & - \\
\hline $13: 0$ anteiso & 0.13 & - & - & - & - & - & - \\
\hline $13: 0$ & - & - & 0.44 & - & - & - & - \\
\hline $14: 0$ iso & 8.88 & 8.00 & 3.28 & 10.28 & 5.87 & 8.90 & 12.70 \\
\hline $14: 1$ cis 9 & - & - & - & - & - & 0.21 & - \\
\hline $14: 0$ & 0.52 & 0.56 & 1.91 & 1.85 & 1.55 & 1.27 & - \\
\hline $15: 1$ iso & 0.23 & - & - & - & - & - & - \\
\hline $15: 0$ iso & 10.07 & 3.58 & 14.45 & 9.90 & 5.63 & 6.15 & 6.55 \\
\hline $15: 0$ anteiso & 8.20 & 2.57 & 11.33 & 16.21 & 6.25 & 3.79 & 4.26 \\
\hline $15: 1$ cis 9 & 0.79 & 1.24 & 1.38 & - & 0.84 & 1.47 & 0.93 \\
\hline $15: 0$ & 1.01 & 0.75 & 7.00 & 2.21 & 2.53 & 1.00 & 0.58 \\
\hline $16: 1$ iso & 3.83 & 9.27 & 0.62 & - & 1.85 & 4.05 & 10.07 \\
\hline $16: 0$ iso & 47.40 & 55.63 & 19.29 & 23.47 & 31.97 & 45.03 & 45.60 \\
\hline $16: 1$ cis 9 & 4.64 & 9.66 & 8.42 & 8.70 & 16.26 & 15.52 & 8.87 \\
\hline $\begin{array}{l}15: 0 \text { anteiso } \\
2-\mathrm{OH}\end{array}$ & - & - & 1.12 & - & - & - & - \\
\hline $16: 0$ & 1.9 & 2.21 & 9.91 & 17.08 & 12.01 & 4.01 & 2.07 \\
\hline 16:0 10-methyl & - & 3.04 & - & 4.14 & 5.48 & 1.40 & 4.10 \\
\hline $17: 1$ iso & 1.39 & - & 1.12 & - & - & - & - \\
\hline $17: 1$ anteiso & 0.68 & - & - & - & - & - & - \\
\hline $17: 0$ iso & 1.21 & - & 2.22 & - & 0.77 & 0.58 & - \\
\hline $17: 0$ anteiso & 4.61 & 0.97 & 5.64 & 4.01 & 2.32 & 1.18 & 1.42 \\
\hline $17: 1$ cis 9 & 1.95 & 1.57 & 4.14 & - & 2.09 & 1.87 & 1.48 \\
\hline $17: 1$ cis 11 & 1.03 & - & - & - & - & 2.49 & - \\
\hline $16: 0$ iso $2-\mathrm{OH}$ & - & 0.95 & 0.63 & - & 1.08 & - & 1.35 \\
\hline $17: 0$ & 0.65 & - & 4.75 & 2.16 & 1.62 & 0.39 & - \\
\hline $17: 0$ 10-methyl & 0.18 & - & - & - & - & - & - \\
\hline $18: 0$ iso & 0.34 & - & - & - & - & - & - \\
\hline $18: 1$ cis 9 & 0.17 & - & 0.75 & - & 1.03 & 0.69 & - \\
\hline $18: 0$ & - & - & 1.05 & - & 0.84 & - & - \\
\hline
\end{tabular}

\section{Description of Lentzea kentuckyensis sp. nov.}

Lentzea kentuckyensis (ken.tuc.ky.en'sis. N.L. fem. adj. kentuckyensis from Kentucky, named after the place of origin of the type strain, the state of Kentucky, USA).

Yellow to strong-yellow substrate mycelium is produced on most media. Aerial mycelium ranging in colour from white to yellowish white is produced on most media. A faint-brown, soluble pigment is produced on some media. Micromorphological and chemotaxonomic characteristics are typical for the genus Lentzea. Casein, aesculin, gelatin, hypoxanthine, tyrosine, urea and xanthine are hydrolysed or decomposed. Adenine and allantoin are not hydrolysed or decomposed. Nitrate is not reduced. Phosphatase is not produced. Malate, oxalate, and succinate are assimilated; citrate and lactate are assimilated weakly. Acetate,
Table 2. Differential physiological properties of strain LDDC $2876-05^{\top}$ and type strains of Lentzea species

Strains: 1, LDDC $2876-05^{\mathrm{T}} ; 2$, L. albidocapillata NRRL B-24057 $; 3$, L. albida NRRL B-24073 $;$; , L. californiensis NRRL B- $16137^{\mathrm{T}} ; 5$, L. flaviverrucosa JCM $113873^{\mathrm{T}} ; 6$, L. violacea IMSNU $50388^{\mathrm{T}} ; 7, L$. waywayandensis NRRL B- $16159^{\mathrm{T}}$. Data obtained in this study except for L. flaviverrucosa (data from Xie et al., 2002) and L. violacea (data from Lee et al., 2000). +, Positive; W, weakly positive; -, negative; ND, not determined.

\begin{tabular}{|lccccccc|}
\hline Characteristic & $\mathbf{1}$ & $\mathbf{2}$ & $\mathbf{3}$ & $\mathbf{4}$ & $\mathbf{5}$ & $\mathbf{6}$ & $\mathbf{7}$ \\
\hline Hydrolysis of: & & & & & & & \\
Casein & + & + & + & + & - & + & + \\
Urea & + & $\mathrm{W}$ & $\mathrm{W}$ & + & - & + & + \\
Nitrate reductase & - & - & - & + & + & - & + \\
Assimilation of: & & & & & & & \\
Acetate & - & - & + & + & + & + & + \\
Citrate & $\mathrm{W}$ & - & + & + & $\mathrm{ND}$ & - & + \\
Lactate & $\mathrm{W}$ & - & - & - & - & + & + \\
Malate & + & + & + & + & + & - & + \\
Acid from: & & & & & & & \\
Adonitol & - & + & + & - & - & - & + \\
Cellobiose & + & + & + & + & + & - & + \\
Inositol & + & + & + & + & + & - & + \\
Maltose & + & + & + & + & + & - & + \\
Mannitol & + & + & + & + & + & - & + \\
Raffinose & + & $\mathrm{W}$ & - & + & + & + & + \\
Rhamnose & + & + & + & + & - & - & + \\
Sucrose & + & + & + & + & + & - & + \\
Trehalose & + & + & + & + & - & - & + \\
Xylose & + & + & + & + & - & - & + \\
Growth at: & & & & & & & + \\
$10{ }^{\circ} \mathrm{C}$ & + & + & - & + & $\mathrm{ND}$ & + & + \\
$37{ }^{\circ} \mathrm{C}$ & + & + & + & + & + & + & $\mathrm{W}$ \\
$42{ }^{\circ} \mathrm{C}$ & - & - & + & - & + & - & - \\
$45{ }^{\circ} \mathrm{C}$ & - & - & + & - & - & - & - \\
& & & & & & & \\
\hline
\end{tabular}

benzoate, mucate, propionate and DL-tartrate are not assimilated. Acid is produced from arabinose, cellobiose, dextrin, D-fructose, D-galactose, D-glucose, glycerol, myoinositol, lactose, maltose, mannitol, D-mannose, melibiose, raffinose, rhamnose, salicin, sucrose and xylose. Acid is produced weakly from methyl $\alpha$-D-glucoside and $\mathrm{D}$-sorbitol. Acid is not produced from adonitol, dulcitol, mesoerythritol, melezitose or methyl $\beta$-xyloside. Growth occurs in the presence of $\mathrm{NaCl}$ concentrations up to $7 \%(\mathrm{w} / \mathrm{v})$. Temperature range for growth is $10-37{ }^{\circ} \mathrm{C}$.

The type strain, LDDC $2876-05^{\mathrm{T}}$ (=NRRL B-24416 ${ }^{\mathrm{T}}$ $=$ DSM $44909^{\mathrm{T}}$ ), was isolated from an equine placenta in Lexington, KY, USA.

\section{Acknowledgements}

The able technical assistance of E. N. Hoekstra with regard to physiological characterization is gratefully acknowledged. Names are necessary to report factually on available data; however, the USDA neither guarantees nor warrants the standard of the product, and the 
use of the name by USDA implies no approval of the product to the exclusion of others that may also be suitable.

\section{References}

De Ley, J., Cattoir, H. \& Reynaerts, A. (1970). The quantitative measurement of DNA hybridization from renaturation rates. Eur $J$ Biochem 12, 133-142.

Donahue, J. M. \& Williams, N. M. (2000). Emergent causes of placentitis and abortion. Vet Clin North Am Equine Pract 16, 443-456.

Donahue, J. M., Williams, N. M., Sells, S. F. \& Labeda, D. P. (2002). Crossiella equi sp. nov., isolated from equine placentas. Int J Syst Evol Microbiol 52, 2169-2173.

DSMZ (2001). Catalogue of Strains. Braunschweig: Deutsche Sammlung von Mikroorganismen und Zellkulturen.

Felsenstein, J. (1989). PHYLIP (phylogeny inference package), version 3.5.1. Distributed by the author. Department of Genome Sciences, University of Washington, Seattle, USA.

Galtier, N., Gouy, M. \& Gautier, C. (1996). SeaView and PHYLO_WIN, two graphic tools for sequence alignment and molecular phylogeny. Comput Applic Biosci 12, 543-548.

Giles, R. C., Donahue, J. M., Hong, C. B., Tuttle, P. A., PetritesMurphy, M. B., Poonacha, K. B., Roberts, A. W., Tramontin, R. R., Smith, B. \& Swerczek, T. W. (1993). Causes of abortion, stillbirth, and perinatal death in horses: 3,527 cases (1986-1991). J Am Vet Med Assoc 203, 1170-1175.

Gordon, R. E., Barnett, D. A., Handerhan, J. E. \& Pang, C. H.-N. (1974). Nocardia coeliaca, Nocardia autotrophica, and the nocardin strain. Int J Syst Bacteriol 24, 54-63.

Grund, E. \& Kroppenstedt, R. M. (1989). Transfer of five Nocardia species to the genus Saccharothrix Labeda et al. 1984. Syst Appl Microbiol 12, 267-274.

Hong, C. B., Donahue, J. M., Giles, R. C., Petrites-Murphy, M. B., Poonacha, K. B., Roberts, A. W., Smith, B. J., Tamontin, R. R., Tuttle,
P. A. \& Swerczek, T. W. (1993). Etiology and pathology of equine placentitis. J Vet Diagn Invest 5, 56-63.

Kimura, M. (1980). A simple method for estimating evolutionary rates of base substitutions through comparative studies of nucleotide sequences. J Mol Evol 16, 111-120.

Kurup, P. V. \& Schmitt, J. A. (1973). Numerical taxonomy of Nocardia. Can J Microbiol 19, 1035-1048.

Labeda, D. P. \& Kroppenstedt, R. M. (2000). Phylogenetic analysis of Saccharothrix and related taxa: proposal for Actinosynnemataceae fam. nov. Int J Syst Evol Microbiol 50, 331-336.

Labeda, D. P., Donahue, J. M., Williams, N. M. \& Sells, S. F. (2003). Amycolatopsis kentuckyensis sp. nov., Amycolatopsis lexingtonensis sp. nov., and Amycolatopsis pretoriensis sp. nov., isolated from equine placentas. Int J Syst Evol Microbiol 53, 1601-1605.

Lee, S. D., Kim, E. S., Roe, J.-H., Kim, J., Kang, S.-O. \& Hah, Y. C. (2000). Saccharothrix violacea sp. nov., isolated from a gold mine cave, and Saccharothrix albidocapillata comb. nov. Int J Syst Evol Microbiol 50, 1315-1323.

Ludwig, W., Strunk, O., Westram, R., Richter, L., Meier, H., Yadhukumar, Buchner, A., Lai, T., Steppi, S. \& other authors (2004). ARB: a software environment for sequence data. Nucleic Acids Res 32, 1363-1371.

Minnikin, D. E., O’Donnell, A. G., Goodfellow, M., Alderson, G., Athalye, M., Schaal, K. \& Parlett, J. H. (1984). An integrated procedure for the extraction of bacterial isoprenoid quinones and polar lipids. J Microbiol Methods 2, 233-241.

Saitou, N. \& Nei, M. (1987). The neighbor-joining method: a new method for reconstructing phylogenetic trees. Mol Biol Evol 4, 406-426.

Sasser, M. (1990). Identification of bacteria by gas chromatography of cellular fatty acids. USFCC Newsl 20, 1-6.

Shirling, E. B. \& Gottlieb, D. (1966). Methods for characterization of Streptomyces species. Int J Syst Bacteriol 16, 313-340.

Xie, Q., Wang, Y., Huang, Y., Wu, Y., Ba, F. \& Liu, Z. (2002). Description of Lentzea flaviverrucosa sp. nov. and transfer of the type strain of Saccharothrix aerocolonigenes subsp. staurosporea to Lentzea albida. Int J Syst Evol Microbiol 52, 1815-1820. 